\title{
Archaeological Traces of the Early Harbour Town
}

\author{
I Wayan Ardika
}

\section{Introduction}

Systematic archaeological research at Sembiran and adjacent areas in north-eastern Bali was commenced in 1987. Finds at Sembiran and Pacung included Indian and local potteries, glass and carnelian beads, metal objects, human burials, and other organic materials. The appearance of Indian potteries at Sembiran and Pacung as well as the occurrence of inscriptional data suggest that these sites may have functioned as an ancient port at least from the beginning of the first millennium $\mathrm{AD}$ up to the $12^{\text {th }}$ century AD.

The archaeological research at Sembiran and adjacent areas was inspired by the inscriptional data which were written on 20 copperplate inscriptions dated from AD 922 to AD 1181. In 1965, these inscriptions were divided by the villagers of Sembiran and Julah, and each village kept 10 of these each. Several facts in relation to the village and the inhabitants of Julah were mentioned in these inscriptions. For instance, the inscription of Sembiran A I dated to AD 922 mentioned a market (pasar), and a market officer (ser pasar) at Julah. Apart from that, a regulation concerning stranded ships and their cargos (tawan karang) also appeared in the inscription. It is also mentioned that people who lived in a fortified settlement (kuta) at Julah were attacked by their enemies, forcing some of them to flee to other villages. 
It should be noted that the terms kuta and ser pasar (market officer) are also mentioned in the inscription of Bebetin A I dated to AD 896 (Goris 1954:54). A kuta within the territory of Banwa Bharu is noted in this inscription. Banwa Bharu could have been another port site in north Bali, possibly located near the modern village of Sangsit, about $15 \mathrm{~km}$ west of Julah, where a small port still exists.

The provisions of the banigrama (merchant guild) that resided in kuta are also mentioned in the inscription of Sembiran A II dated AD 975. The term banigrama also occurs in contemporary East Javanese inscriptions, particularly in port areas. From the $10^{\text {th }}$ century Javanese inscriptions, the term banigrama is associated with foreign traders including Chams, Khmers, Mons, Singhalese, Bengalis, Kalingas, Podikiras, Karnataka, Dravidis and Aryyas (Barret Jones 1984:23; Wisseman 1977:207).

The inscription of Sembiran A III dated AD 1016 mentioned the villagers of Julah who had been scattered and fled to other villages. Some of them were killed by enemies. In all, there remained in the village only 50 families out of an original 300. The village therefore asked the Balinese Queen (Sang Ratu Sri Ajnadewi) for a reduction in their taxes and other responsibilities.

An interesting fact concerning seafaring merchants (banyaga) who anchored at Manasa with their ships and boats was also mentioned in the inscription of Sembiran A IV dating from AD 1016 (Ardika 1991:144). Manasa could be another port site in north Bali that is still unknown. Regulations concerning maritime vessels anchored at Julah were also mentioned in the inscription of Sembiran $\mathrm{C}$ dating from AD 1181. The samgat badwa haji and the kabayan gosti had authority to inspect the cargos of these ships (Ardika 1991:148). Based on the contents of these inscriptions, Julah and nearby areas seem to have been involved in maritime trade between the early $10^{\text {th }}$ to $12^{\text {th }}$ centuries AD. During the early 10 th century AD, the trade activities at Julah were probably carried out from a kuta or fortified settlement. The settlement itself was plundered many times, perhaps by pirates, and its inhabitants were sometime killed, captured, or they fled to other villages. Foreign traders or banyaga came to Julah and lived there in a guild (banigrama).

Archaeological excavations at Sembiran and Pacung, which are located less than one kilometre west of the modern village of Julah, have now produced a good deal of data that proves these sites could be an ancient harbour dating at least from the beginning of the first millennium AD. In other words, inscriptional and archaeological data have now been put together that indicate that the coastal areas of Sembiran and Pacung could have been the earliest harbour in northeastern Bali. Geographically, Sembiran and Pacung could be part of ancient Julah, as has been mentioned in several Balinese inscriptions. 


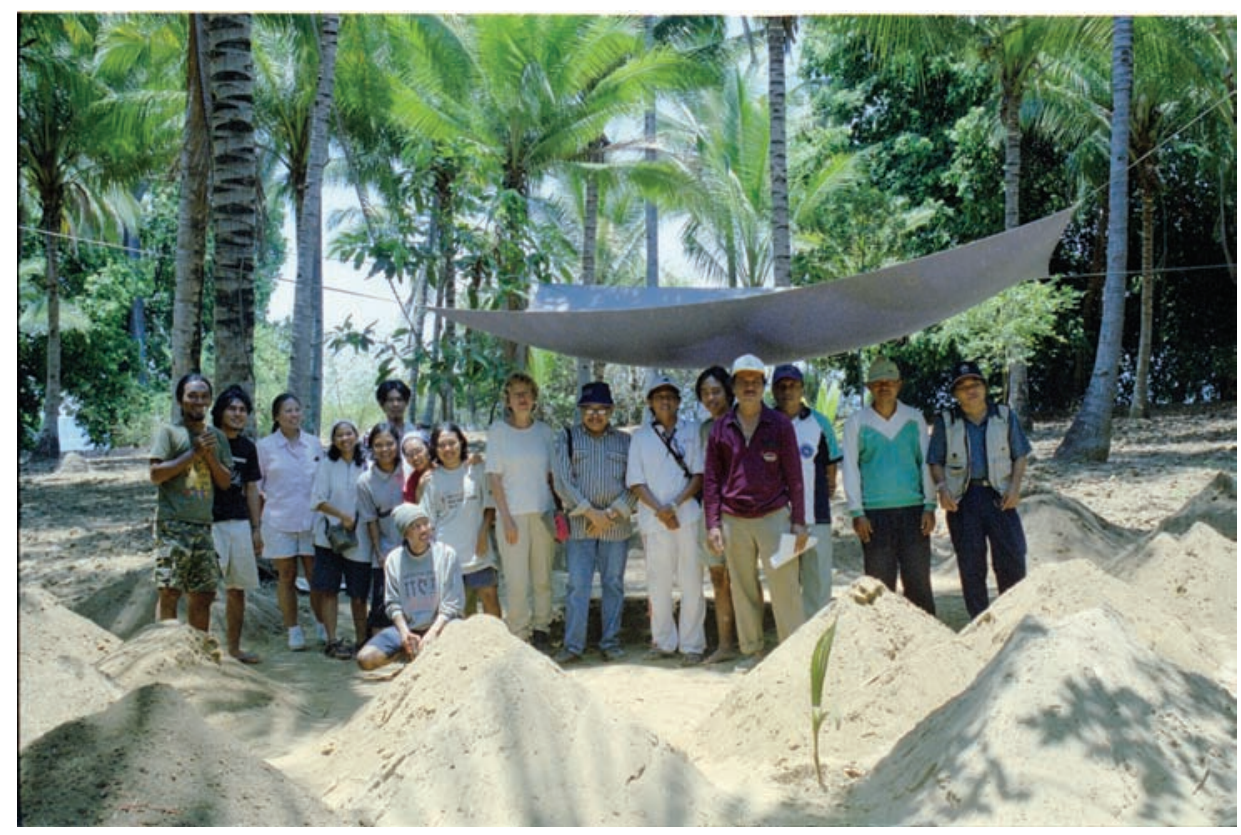

Photo 1: The excavation team (with the two editors of this book in the centre) in Pacung in 2003.

Photo: Jörg Hauser 2003.

\section{Archaeological Discoveries}

Over the last decade, archaeological excavations on the north-eastern coast of Bali, particularly at the sites of Sembiran and Pacung have been continued.

These excavations have produced a large amount of Indian pottery including Rouletted Ware of Arikamedu type 1, potsherds of Arikamedu type 10, a potsherd of Arikamedu type 18, and a potsherd of Arikamedu type 141, named after the archaeological site in the Coromandel Coast, Tamil Nadu (India), a once important port with intermaritime trade relations reaching as far as the Mediterranean Sea and the Roman Empire. So far, Sembiran and Pacung have produced the largest collection of rouletted sherds in Indonesia and Southeast Asia. More than a hundred pieces of rouletted sherds were discovered at Sembiran and Pacung (Ardika 1991). A complete bowl of Rouletted Ware has also been found accidentally at Kobak Kendal in West Java. This site is considered to have been the former site of Taruma Negara kingdom in West Java.

Rouletted Ware was manufactured in India or Sri Lanka between perhaps 150 BC and AD 200. The date of appearance of Rouletted Ware in Bali and Indonesia in general was probably AD 1-200 (Ardika and Bellwood 1991:229). It should be noted that a large black-slipped storage jar was tempered with rice husk found at 
the same layer in association with Rouletted Ware at Sembiran dated by AMS radiocarbon to 2660+/- $100 \mathrm{BP}$ (Ardika and Bellwood 1991).

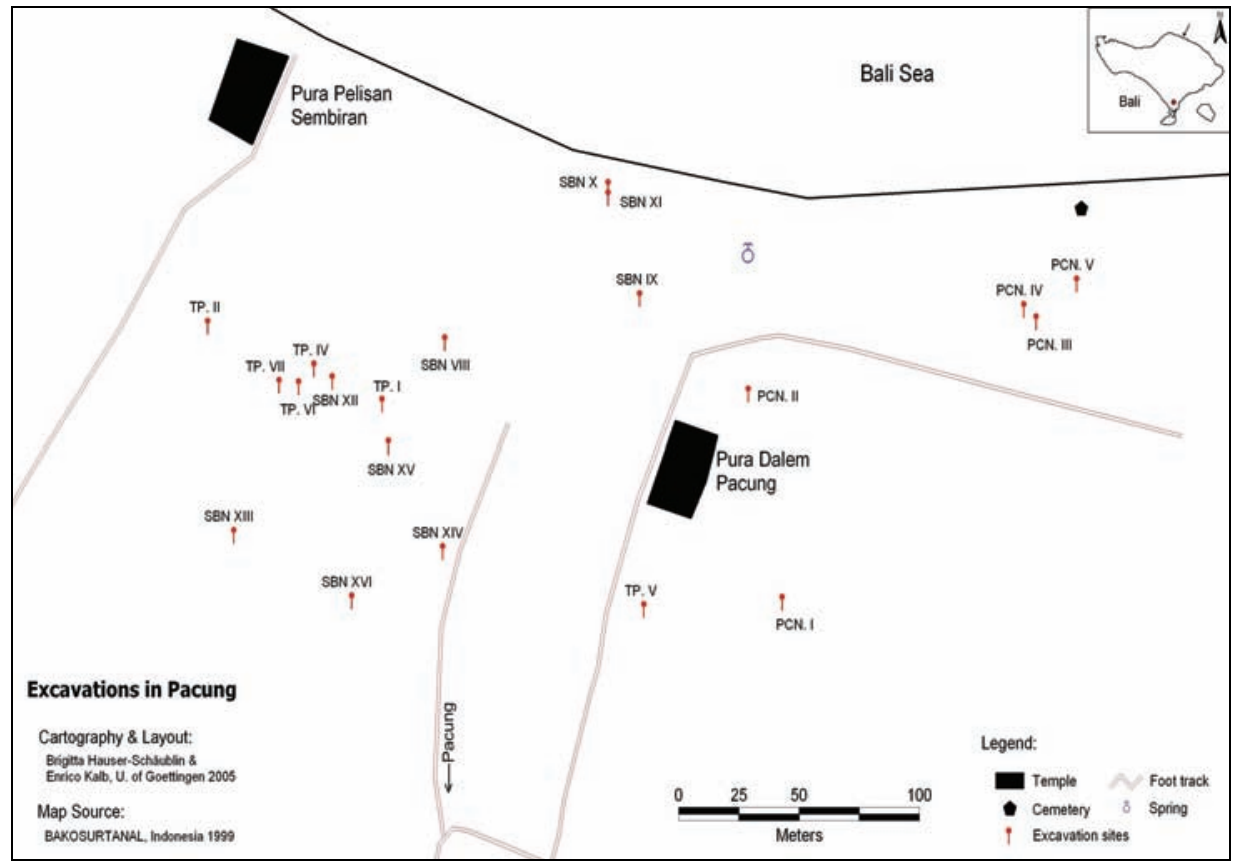

Figure 1: The location of the individual excavations trenches in Pacung.

X-ray diffraction (XRD) analysis has so far been performed on one rouletted sherd from Sembiran IV, four from Anuradhapura and three from Arikamedu. All have essentially the same minerals; mainly quartz with traces of mica, muscovite, potassium feldspar and plagioclase feldspar. The XRD result conclusively supports an Indian origin (Ardika and Bellwood 1991:224; Ardika et al.1993).

In addition to the XRD analysis, nine samples of Rouletted Ware (two from Anuradhapura, two from Arikamedu, one from Karaikadu [Tamil Nadu], three from Sembiran and the single sherd from Pacung) have also been subjected to neutron activation analysis (NAA) for 20 rare elements. The result indicates that all the Rouletted Ware is so similar in composition that a single manufacturing source for all the samples listed has to be supposed. The rouletted sherds cluster completely and separately in principal components and average link cluster analysis from those of presumed Balinese manufacture (Ardika and Bellwood 1991:224; Ardika et al.1993).

Apart from Rouletted Ware, two pieces of sherds of Arikamedu type 10 have also been found at Sembiran. Outside Arikamedu this type of pottery has also been found on the site of Chandraketugarh in West Bengal, and Alangankulam on 
the Vaigai river in Tamil Nadu (Ardika and Bellwood 1991:224). No information is at present available on its occurrence elsewhere.

An inscribed sherd has also been discovered at Sembiran (Ardika and Bellwood 1991:225, fig.4). At first the script was believed to be Brahmi, similar to that used for the Tamil or Prakrit graffiti found on many potsherds from South Indian sites such as Arikamedu, Anuradhapura, and Salihundam. However, according to B.N. Mukherjee of Calcutta University, the script is Kharoshthi, although no definite translation is possible owing to the fragmentary nature of the script.

Beads made of glass or stone were often found in several prehistoric sites in Indonesia. Red glass beads or mutisalah are very common in Southeast Asia as well as in Indonesia. Several sites such as Oc-Eo (Vietnam), Kuala Selinsing and Pangkalan Bujang (Malaysia) produced a large number of glass beads, but are very rare at Ahichchatra, North India. Glass beads were also found in several sites in Indonesia, including Gilimanuk, Sembiran (both sites in Bali), Plawangan (Central Java), Leang Bua (Flores), and Pasemah (South Sumatra). Five glass beads from Sembiran have been analysed by Kishor Basa at the Institute of Archaeology in London. One can be categorized as mixed-alkali glass and four as potash glass. Basa (1991) believes that the Sembiran beads are similar to South Indian samples in terms of raw materials, and were probably manufactured at Arikamedu.

In addition to glass beads, carnelian beads have also been discovered in several prehistoric sites such as Gilimanuk, Sembiran and sarcophagus sites (Nongan, Bona, Selasih, Margatengah, Pujungan, and Ambiarsari) in Bali. These carnelian beads are generally believed to have been imported from India, although some may have been made in Southeast Asia since carnelian scrap occurs in some sites, including Kuala Selinsing in West Malaysia.

Gold foil eye covers have been found in Gilimanuk and in sarcophagus burial sites at Pangkungliplip and Margatengah (Soejono 1977). Similar gold foil eye covers have also been discovered at Oton on Panay Island in the Philippines and at Santubong in Sarawak (O'Connor and Harrisson 1971:72-73). These gold foil eye covers are similar to the artifacts reported from graves at Adichanallur on the Tamil Nadu coast (O’Connor and Harrisson 1971; Ray 1989:51).

Apart from Indian articles, glass and stone beads, as well as metal objects, the majority of archaeological findings in north-eastern Bali are potsherds. These potsherds are very similar in terms of form and decoration to those found in a number of contemporary sites in Southeast Asia. This type of pottery in Southeast Asia is well known as Sa Huyn (Vietnam) - Kalanay (The Phillipines) pottery.

Human burial sites have also been found in several trenches at Sembiran and Pacung. Burial practices at Sembiran and Pacung seem to have consisted of two types, namely primary and secondary burial. In primary burial the corpse was normally put in the ground without a permanent container, and in straight or bent position. In secondary burial, it was sometimes put in a pot used as a container, or 
without a container. Burial accoutrements consisted of potteries, glass and carnelian beads, stone tools, as well as metal objects.

From the year of 1987 up to 2005, there are at least 32 trenches that have been excavated in several villages in north-eastern Bali, including 1 trench at Julah, 7 trenches at Pacung, 20 trenches at Sembiran, 2 trenches at Upit/Batu Gambir, and 2 trenches at Bangkah. These trenches are mainly $1.5 \times 1.5 \mathrm{~m}$ or $2 \times 2 \mathrm{~m}$ in length and between 1.5 and $4.5 \mathrm{~m}$ in depth. Most of the archaeological evidence has been found in the coastal areas of Julah, Pacung, Sembiran, and Bangkah. Only a few potsherds have been found from two trenches that were excavated in the highlands of Sembiran (Sembiran Atas/SBA 1 and 2). The situation is similar at Upit/Batu Gambir. However, there are only small numbers of potsherds that were discovered during the excavation programs at Upit/Batu Gambir. On the basis of archaeological remains it can be assumed that the settlement in northeastern Bali might have been located in the coastal areas, due to geographical setting of north-eastern Bali, which is located on the trade routes connecting the eastern and western part of the Indonesian archipelago.

\section{Trade and Trade Goods}

Archaeological evidence such as Rouletted Ware, glass and carnelian beads and gold foil eye covers, discovered in several prehistoric sites in Indonesia, might have derived from India. The question arises as to what kind of goods or commodities from Indonesia or Southeast Asia were exported to India during prehistoric times; we have so far no definitive answer to this, however the following indications:

High-tin bronze bowls, made in Southeast Asia perhaps as early as 200 BC, might have been exported to India and even as far as Taxila in Pakistan (Glover 1990). Pottery decorated with intricate angular or curvilinear carved-paddle impressed designs, of a type very common throughout at least the past 2000 years in western Island Southeast Asia has also been found in major Indian trading sites of the early historical period such as Arikamedu, Anuradhapura and probably Kantarodai. The finds in India cannot however be assumed to be from Southeast Asian sources without the benefit of chemical analysis (Ardika and Bellwood 1991:230).

It is remarkable to note that both Indian and Classical sources mentioned a number of products from Indonesia. For instances, the Ramayana (prior to AD 200) mentions gharuwood and sandalwood from eastern Indonesia, where the best quality sandalwood was to be found. The Raghuvamsa of Kalidasa (AD 400) mentions cloves (lavanga) with nutmegs indigenous to the Moluccas (Wolters 1967:65-6). Miller (1969) provides detailed list of spices mentioned in Classical texts which are presumed to have been produced in Southeast Asia during the Roman Imperial period. Cloves were known to Pliny in AD 70 (Miller 1969:51), as 
was cinnamon, which probably was grown widely in Sri Lanka and Island Southeast Asia at that time.

It is interesting to note the result of the analysis of ancient mitochondrial DNA from the human tooth of Pacung III in north-eastern Bali. The tooth sample is generally associated with haplogroup $\mathrm{A}$, which clearly clustered closest to Indian sequences followed by most of the Nepalese and Tibetan sequences (i.e., 16240 G, $16261 \mathrm{~T}$ ) (Lansing et al. 2004:288-90). AMS radiocarbon analysis of the tooth indicates its age as 2050 +/- $40 \mathrm{BP}$ (conventional radiocarbon age 2110 +/40 BP) (Lansing et al. 2004:288). In addition, Y-Chromosome data from a sample of 551 modern Balinese men indicate significant prehistoric contacts between India and Bali (Karafet et al. 2005).

On the basis of archaeological data found at Sembiran and Pacung, we can assume that both sites which are very close to each other could be part of an ancient harbour on the north-eastern coast of Bali. In the beginning of the first millennium $\mathrm{AD}$, foreign traders might have come to the site with their goods such as Indian pottery, beads of glass and carnelian, and possibly other products. Foreign traders might have died and been buried in the site or intermarried to local people as indicated by the DNA results from Pacung.

Since archaeological data is still limited, it is impossible to know whether the Balinese or Indonesian traders also travelled to the Indian continent at the beginning of our century. This kind of question needs to be raised in order to understand the mechanisms and processes of trade between foreigners and the local people of Bali in the past.

As mentioned before, all the evidence indicates that Sembiran and adjacent areas could have been a harbour on the north-eastern coast of Bali dating from the beginning of the first millennium AD up to $12^{\text {th }}$ century AD. Sembiran might have been located on the trade route between eastern and western part of the Indonesian archipelago. It is not clear why the site ceased functioning as a harbour after $12^{\text {th }}$ century AD. Archaeological excavations at Sembiran and Pacung suggest that the erosion and sedimentation process reached a depth of 4 meters within 2000 years. This erosion and sedimentation process could be another factor besides social disturbance that caused the end of Sembiran harbour in north-eastern Bali after $12^{\text {th }}$ century.

\section{Conclusion}

Archaeological and inscriptional data suggest that Sembiran or the ancient village territory of Julah could have been one of the ancient harbour in north-eastern Bali. Trade activities might have taken place in a market place within a fortified settlement. DNA analysis indicates that foreign traders presumably may have come to the site and intermarried with local people. Genetic data also strongly suggest the presence of contacts between India and Indonesia, and particularly 
Bali, during prehistoric times. These contacts supposedly have been stimulated by the appearance of a world trade system in these regions (Glover 1990).

\section{References}

Ardika, I Wayan

1991 Archaeological Research in Northeastern Bali, Indonesia. Dissertation. Canberra: Australian National University.

Ardika, I W. and P. Bellwood

1991 Sembiran: the Beginnings of Indian Contact with Bali. Antiquity 65, 247: 221232.

Ardika, I W., Bellwood, P., Eggleton, R.A. and D.J. Ellis

1993 Single Source for South Asian Export-Quality Rouletted Ware. Man and Environment XVIII, 1 (January-June): 101-109.

Ardika, I W., Bellwood P.S., Sutaba, I.M. and K. Citha Yuliathi

1997 Sembiran and the First Indian Contacts with Bali: an Update. Antiquity 71, 271: 193-195.

Barret Jones, A.M.

1984 Early Tenth Century Java from the Inscriptions. Leiden: Koninklijk Instituut voor Taal-, Land- en Volkenkunde.

Basa, K.

1991 The Westerly Trade of Southeast from c. 400 BC to AD 500 with Special Reference to Glass Beads. Unpublished Ph.D. Thesis. London: University of London.

Glover, I.C.

1990 Early Trade Between India and Southeast Asia. Link in the Development of a World Trading System. Hull: Centre for Southeas Asian Studies. The University of Hull.

Goris, R.

1954 Prasasti Bali. Lembaga Bahasa dan Budaya. Fakultas Sastra dan Filsafat, Universitas Indonesia. Bandung: Masa Baru.

Karafet, T.M. et al.

2005 Balinese Y-Chromosome Perspective on the Peopling of Indonesia: Genetic Contributions from Pre-Neolithic Hunter-Gatherers, Austronesian Farmers and Indian Traders. Human Biology 77, 1: 93-113.

Lansing, J.S., Redd, A.J., Karafet, T.M., Watkins J., W. Ardika et al.

2004 An Indian Trader in Ancient Bali? Antiquity 78, 300: 287-293.

Miller, J.I.

1969 The Spice Trade of the Roman Empire. Oxford: Clarendon. 
O'Connor, S.J. and T. Harrisson

1971 Gold-foil Burial Amulets in Bali, Philippines and Borneo. Journal of Malaysian Branch of the Royal Asiatic Society 44, 1: 71-77.

Ray, H.P.

1989 Early Maritime Contacts between South and Southeast Asia. Journal of Southeast Asian Studies XX, 1: 42-54.

1994 The Winds of Change. Buddhism and the Maritime Links of Early South Asia. Delhi: Oxford University Press.

Soejono, R.P.

1977 Sistem-Sistem Penguburan pada Akhir Masa Prasejarah di Bali. Unpublished Dissertation. Jakarta: University of Udayana.

Wheeler, R.E.M., Ghosh, A. and Krishna Deva

1946 Arikamedu: an Indo-Roman Trading Station on the East Coast of India. Ancient India 2: 17-124.

Wisseman-Christie, J.

1977 Market and Trade in Pre-Majapahit Java. In: Hutterer, K.L. (ed): Economic Exchange and Social Interaction in Southeast Asia: Perspectives from Prehistory, History, and Ethnography; pp. 108-118. Michigan Papers on South and Southeast Asia, Vol. 13. Ann Arbor: The University of Michigan.

Wolters, O.W.

1967 Early Indonesian Commerce. Ithaca \& London: Cornell University Press. 